\title{
Fish biomass and species composition in the Malta Reservoir, Poland
}

\author{
Wojciech ANDRZEJEWSKI ${ }^{1)}$, Jacek SZLAKOWSKI'), \\ Jerzy MASTYŃSKII), Jan MAZURKIEWICZ ${ }^{1)}$, \\ Matgorzata GODLEWSKA ${ }^{2}$
}

1) Poznan University of Life Sciences, Institute of Zoology, Division of Inland Fisheries and Aquaculture, ul. Wojska Polskiego 71C, 60-625 Poznań, Poland; karp@up.poznan.pl

2) Inland Fisheries Institute in Olsztyn, Department of River Fisheries at Żabieniec, ul. Główna 48, 05-500 Piaseczno, Poland; rzeki@infish.com.pl

\begin{abstract}
In the Malta Reservoir a total of 16 fish species belonging to six families were recorded in 2008. In the Nordic multi-mesh gillnets 4528 fish belonging to 11 species, with the total weight of $149.5 \mathrm{~kg}$, were caught. The total beach seine catch was $34348.9 \mathrm{~kg}$, which in terms of the reservoir area of 64 ha amounted to biomass density $536.7 \mathrm{~kg} \cdot \mathrm{ha}^{-1}$. Of 11 species caught with the beach seine roach (Rutilus rutilus) was the most abundant species (485031 fish, 7578 individuals $\cdot \mathrm{ha}^{-1}$ ) with the highest share in biomass $(24283.4 \mathrm{~kg}, 70.7 \%)$. The average electric catch at two sampling sites in the Cybina River running in the reservoir bowl was $105 \mathrm{~kg}$ (which gave estimate of 2.6 ton in all), with a marked dominance of the roach, which constituted $65.4 \%$ of fish catch in weight and $93 \%$ in numbers. Taking under consideration the results of electrofishing the estimated fish density in the Malta Reservoir in 2008 could reach as much as $577.7 \mathrm{~kg} \cdot \mathrm{ha}^{-1}$. The proportion of predatory fish in the fish assemblage biomass was $20.1 \%$.
\end{abstract}

Key words: biomass estimates, ichthyofauna, Malta Reservoir, species structure

\section{INTRODUCTION}

The Malta Reservoir is an unique retention reservoir on the European scale, since due to its primary function (an international water sports centre), starting from 1992 it has been completely drained at 4-year intervals. Drainage, together with the related fish catching, is the most reliable method to estimate fish biomass and to determine fish species occurring in a given reservoir (WAJDOWICZ, 1971; $\mathrm{SYCH}, 1997)$.

The possibility to directly estimate fish biomass in reservoirs, at their drainage, is exceptional. Most frequently indirect methods are applied, such as catching 
the tagged part of the population (EPLER and BIENIARZ, 1977; PIVNIČKA and ŠVATORÁ, 1988), calculation of catch per unit effort of towed fishing gear (beach seine) (JELONEK and AMIROWICZ, 1987a; KUBEČKA and BOHM, 1991), analysis of catch per unit effort (WIŚNIEWOLSKI, 2002) or by estimating fish biomass on the basis of exploited fish species catches with known biological and exploitation parameters (SZLAKOWSKI and WIŚNIEWOLSKI, 2001). Occasionally data on the fish biomass in a reservoir are supplied by ecological disasters, such as fish mass mortality due to oxygen depletion in the Włocławek Reservoir in 1986 (SYCH, 1997; WIŚNIEWOLSKI, 2000). Frequently such results need to be treated as rough approximations, but in view of no other feasible option or a lack of profitability for other methods which might be applied, they remain the only available ones.

Hydroacoustic methods, being intensively developed, seem promising tools in the estimation of fish biomass, including that in shallow reservoirs (GODLEWSKA et al., 2009; KUBEČKA et al., 2009).

The species/size structure of fish living in reservoirs is affected by many factors, primarily by environmental factors of both the reservoir itself and the supplying watercourse, as well as anthropogenic factors and the adopted fishery-angling management. Conditions affecting fisheries and angling management in reservoirs were presented by WIŚNIEWOLSKI (2002; 2009).

The aim of this paper is to describe pattern of changes of fish assemblage and its biomass in the periodically drained Malta Reservoir between 1966-2008.

\section{MATERIALS AND METHOD}

The Malta Reservoir $\left(52^{\circ} 24^{\prime} \mathrm{N}, 16^{\circ} 58^{\prime} \mathrm{E}\right)$, located in the central part of Poznań, Poland, was created in 1952 by damming the waters of the Cybina River at km $0+492$. The area of the reservoir is 64 ha, volume $2 \cdot 10^{6} \mathrm{~m}^{3}$, mean depth $2.8 \mathrm{~m}$, while maximum depth is $5.5 \mathrm{~m}$. The average retention time is 34 days, at the mean flow of the Cybina River of $0.67 \mathrm{~m}^{3} \cdot \mathrm{s}^{-1}$. The Cybina River bed remaining in the reservoir is $2.5 \mathrm{~km}$ long, $1.6 \mathrm{~m}$ deep and $5 \mathrm{~m}$ wide.

For the purpose of preliminary determination of fish species composition and size structure, the Nordic multi-mesh bottom gillnets $(8$ pcs.) which are the European standard in experimental catches (CEN, 2005), were applied. Bottom Nordic gillnet consists of 12 panels with mesh sizes from 5 to $55 \mathrm{~mm}, 2.5 \mathrm{~m}$ in length each and high $1.5 \mathrm{~m}$. Experimental catches in the Malta Reservoir were conducted in September and October 2008. Multi-mesh gillnets were set for approx. $10 \mathrm{~h}$, between 7:30 and 9:30 p.m. and lifted the following morning between 6:30 and 7:30 a.m. The catch was sorted to species, weighted and total length of each individual fish was measured to the millimeter below.

Analyses of fish species composition and estimation of fish biomass were conducted in October and November 2008 during the Malta Reservoir drainage. 
Fish were caught by a fishery team using a beach seine with a wing length of 150 $\mathrm{m}$, mesh size $25 \mathrm{~mm}$ in the wing and $12 \mathrm{~mm}$ in the cod end. In order to reduce the number of fish flowing out of the reservoir a barrier net was set at its discharge. Water discharge rate was dependent on atmospheric conditions and on the progress of works connected with fish capture. From beach seine catches 15 samples were collected at random, with a total weight of $624 \mathrm{~kg}$, which were used to determine species composition and the mean weight of a given species (for fish over $10 \mathrm{~cm}$ in total length) and subsequent calculation of fish abundance and proportions of individual species in catches.

After completion of fish catches and complete drainage of the reservoir, in the Cybina River bed running in the reservoir bowl, electric fishing was performed at two sites of $100 \mathrm{~m}$ in length each. As previously, fish were identified to species, counted and weighted.

\section{RESULTS}

A total of 16 fish species belonging to six families: Acipenseridae, Anguillidae, Cyprinidae, Siluridae, Esocidae and Percidae were identified in the Malta Reservoir in 2008 catches. Gudgeon (Gobio gobio) was recorded only during electrofishing.

A total of 4528 fish of 11 species, with the total weight of $149.5 \mathrm{~kg}$, were caught in the Nordic multi-mesh gillnets (Tab. 1). The proportion of roach (Rutilus rutilus), a species dominating in the catches, was $64.5 \%$ in numbers and $38.8 \%$ in catch weight. Contribution of the next two species, perch (Perca fluviatilis) and ruffe (Gymnocephalus cernuus), amounted to 16.8 and $11.5 \%$ in numbers and 25.8 and $4.5 \%$ in catch weight, respectively. Thanks to the high unit weight, the proportion of predatory species, pikeperch (Sander lucioperca) and pike (Esox lucius), was $27.4 \%$ in catch weight, but only $0.7 \%$ in numbers.

The total catch in weight with the beach seine was $34348.9 \mathrm{~kg}$, what at the reservoir area of $64 \mathrm{ha}$, gave the biomass density $536.7 \mathrm{~kg} \cdot \mathrm{ha}^{-1}$ (Tab. 2). Roach was the most abundant species in numbers 485031 fish $(75.5 \%)$ or 7578 individuals $\cdot \mathrm{ha}^{-1}$ and $24283.4 \mathrm{~kg}(70.7 \%)$ in catch weight. Perch contribution, the second

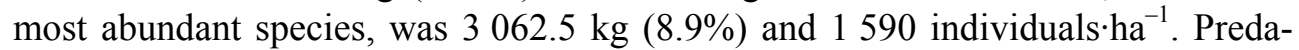
tory fish, i.e. pikeperch, wels (Silurus glanis) and pike, accounted for only $11.1 \%$ of the total catch weight. Together with perch, the proportion of predatory fish in the catch weight was $20 \%$. While smaller perch, with the total length below $15 \mathrm{~cm}$, is rather omnivorous than definite predator, larger specimens preyed intensively on small roach, including those gilled in the small meshes of the Nordic multi-mesh gillnets. 
Table 1. Results of Nordic multi-mesh gillnets catches in the Malta Reservoir in 2008

\begin{tabular}{l|r|r|r|r|c}
\hline \multicolumn{1}{c}{ Species } & \multicolumn{1}{c}{$\begin{array}{c}n \\
\text { no. }\end{array}$} & \multicolumn{1}{c}{$\begin{array}{c}n \\
\%\end{array}$} & $\begin{array}{c}\text { Weight } \\
\mathrm{g}\end{array}$ & $\begin{array}{c}\text { Weight } \\
\%\end{array}$ & $\begin{array}{c}\text { Length range } \\
\mathrm{cm}\end{array}$ \\
\hline Perch (Perca fluviatilis) & 762 & 16.8 & 38507 & 25.8 & $6.5-40.0$ \\
Pike-perch (Sander lucioperca) & 20 & 0.4 & 23336 & 15.6 & $13.3-60.5$ \\
Pike (Esox lucius) & 12 & 0.3 & 17641 & 11.8 & $51.0-68.2$ \\
Total predators & 794 & 17.5 & 79484 & 53.2 & \\
Roach (Rutilus rutilus) & 2920 & 64.5 & 57983 & 38.8 & $5.3-28.6$ \\
Ruffe (Gymnocephalus cernuus) & 519 & 11.5 & 6670 & 4.5 & $6.3-13.2$ \\
Bream (Abramis brama) & 258 & 5.7 & 4334 & 2.9 & $5.3-33.8$ \\
Rudd (Scardinius erythrophthalmus) & 10 & 0.2 & 518 & 0.3 & $10.7-28.0$ \\
Tench (Tinca tinca) & 1 & $<0.1$ & 285 & 0.2 & 28.0 \\
Bleak (Alburnus alburnus) & 17 & 0.4 & 142 & 0.1 & $6.4-16.7$ \\
White bream (Blicca bjoerkna) & 4 & 0.1 & 39 & $<0.1$ & $13.4-23.6$ \\
Sunbleak (Leucaspius delineatus) & 5 & 0.1 & 10 & $<0.1$ & $4.4-8.8$ \\
Total non-predatory species & 3734 & 82.6 & 69981 & 46.8 & \\
Total & 4528 & 100.0 & 149465 & 100.0 & \\
\hline
\end{tabular}

Table 2. Results of beach seine catches in the Malta Reservoir in 2008

\begin{tabular}{l|r|r|r|r|r}
\hline \multicolumn{1}{c|}{ Species } & \multicolumn{1}{c}{$\begin{array}{c}n \\
\text { no. }\end{array}$} & \multicolumn{1}{c}{$\begin{array}{c}n \\
\%\end{array}$} & $\begin{array}{c}\text { Weight } \\
\mathrm{kg}\end{array}$ & $\begin{array}{c}\text { Weight } \\
\%\end{array}$ & $\begin{array}{c}\text { Biomass } \\
\text { density } \\
\mathrm{kg} \mathrm{ha}^{-1}\end{array}$ \\
\hline Perch (Perca fluviatilis) & 101779 & 16.3 & 3062.5 & 8.9 & 47.9 \\
Pike-perch (Sander lucioperca) & 775 & 0.1 & 1572.0 & 4.6 & 24.6 \\
Wels (Silurus glanis) & 758 & 0.1 & 1288.0 & 3.7 & 20.1 \\
Pike (Esox lucius) & 694 & 0.1 & 974.0 & 2.8 & 15.2 \\
Eel (Anguilla anguilla) & 26 & $<0.1$ & 26.0 & 0.1 & 0.4 \\
Total predators & 104032 & 16.6 & 6922.5 & 20.1 & 108.2 \\
Roach (Rutilus rutilus) & 485031 & 77.5 & 24283.4 & 70.7 & 379.4 \\
Bream (Abramis brama) & 23148 & 3.7 & 2189.0 & 6.4 & 34.2 \\
Tench (Tinca tinca) & 803 & 0.1 & 618.0 & 1.8 & 9.7 \\
Ruffe (Gymnocephalus cernuus) & 12409 & 2.0 & 273.0 & 0.8 & 4.3 \\
Prussian carp (Carassius gibelio) & 43 & $<0.1$ & 38.0 & 0.1 & 0.6 \\
Atlantic sturgeon (Acipenser oxyrinchus) & 10 & $<0.1$ & 25.0 & $<0.1$ & 0.4 \\
Total non-predatory species & 521444 & 83.4 & 27426.4 & 79.9 & 428.5 \\
Total & 625476 & 100.0 & 34348.9 & 100.0 & 536.7 \\
\hline
\end{tabular}

Both in the experimental and commercial catches, the proportion of bream (Abramis brama), constituting usually together with roach most of the fish assemblage biomass, did not exceed $5.7 \%$ in numbers and $6.4 \%$ in catch weight. 
An average electric catch at two sites in the Cybina River was $105 \mathrm{~kg}$. Roach predominated in the catches, accounting for $93 \%$ in numbers and $65.4 \%$ in catch weight. The share of perch and pikeperch were $3 \%$ and $0.6 \%$ in numbers, and $4.7 \%$ and $27.8 \%$ in catch weight, respectively. It can be estimated that after complete drainage of the reservoir in the old river bed there still remained at least 2.6 ton of fish. Thus, the biomass density in the Malta Reservoir in 2008 could reach 577.7 $\mathrm{kg} \cdot \mathrm{ha}^{-1}$.

Multi-modal distributions of length of roach, bream and perch indicate that populations of these species are composed of at least several age groups, including specimens aged above 4+ (Fig. 1). We know from direct observations that some fish, after the reservoir has been drained, remain in the old river bed and free immigration of fish to the reservoir with the flow of the Cybina River is hindered. Thus roach with the total length over $15 \mathrm{~cm}$, bream over $37 \mathrm{~cm}$ and perch of more than $25 \mathrm{~cm}$ remained in the reservoir after it had been drained in 2004. Fish of these sizes are already sexually mature, what promotes rapid restoration of the biomass, after the reservoir is refilled.

\section{DISCUSSION}

The Malta Reservoir was drained eight times between 1966-2008 (Fig. 2). In the years preceding the drainage in 1966 and 1970 the reservoir had been subjected to fishery management and the estimates of biomass did not include juveniles and weight of fish of minor importance, such as white bream (Blicca bjoerkna), threespined stickleback (Gasterosteus aculeatus), ruffe, chub (Leuciscus cephalus), bleak (Alburnus alburnus), dace (Leuciscus leuciscus) and ide (Leuciscus idus), which could have affected the lower biomass density estimates (MASTYŃSKI, 1971; MASTYŃSKI and ANDRZEJEWSKI, 1996). In 1980 all collected species were recorded and the estimated biomass density was $438.1 \mathrm{~kg} \mathrm{ha}^{-1}$ (MASTYŃSKI, 1984). Starting from that year the reservoir was reclaimed and the accumulated sediments were removed. The reservoir was flooded again in 1990, at the same time excluding it from recreational fisheries. During the drainage in 1992 biomass density was estimated at $398.5 \mathrm{~kg} \cdot \mathrm{ha}^{-1}$, with bream $(37 \%)$, roach $(28 \%)$ and small perch (16.5\%) dominating in catch (MASTYŃSKI and KLIMASZYK, 1994). In order to maintain the population of fish feeding on zooplankton (juveniles and small cyprinids, also small perch) on a low level, the Malta Reservoir was subjected to biomanipulation in 1993-1996. The reservoir was stocked with stocking material of varying assortment of pike, pikeperch, wels and eel (Anguilla anguilla) (GOŁDYN, 1996). Biomanipulation efforts were only partially successful, resulting in a periodical decrease in the trophic status of the reservoir, but they did not reduce the fish biomass, which density was $385.2 \mathrm{~kg} \cdot \mathrm{ha}^{-1}$ in 1996 (GOŁDYN and MASTYŃSKI, 1998). One of the causes could have been too small amount of stocking material of 

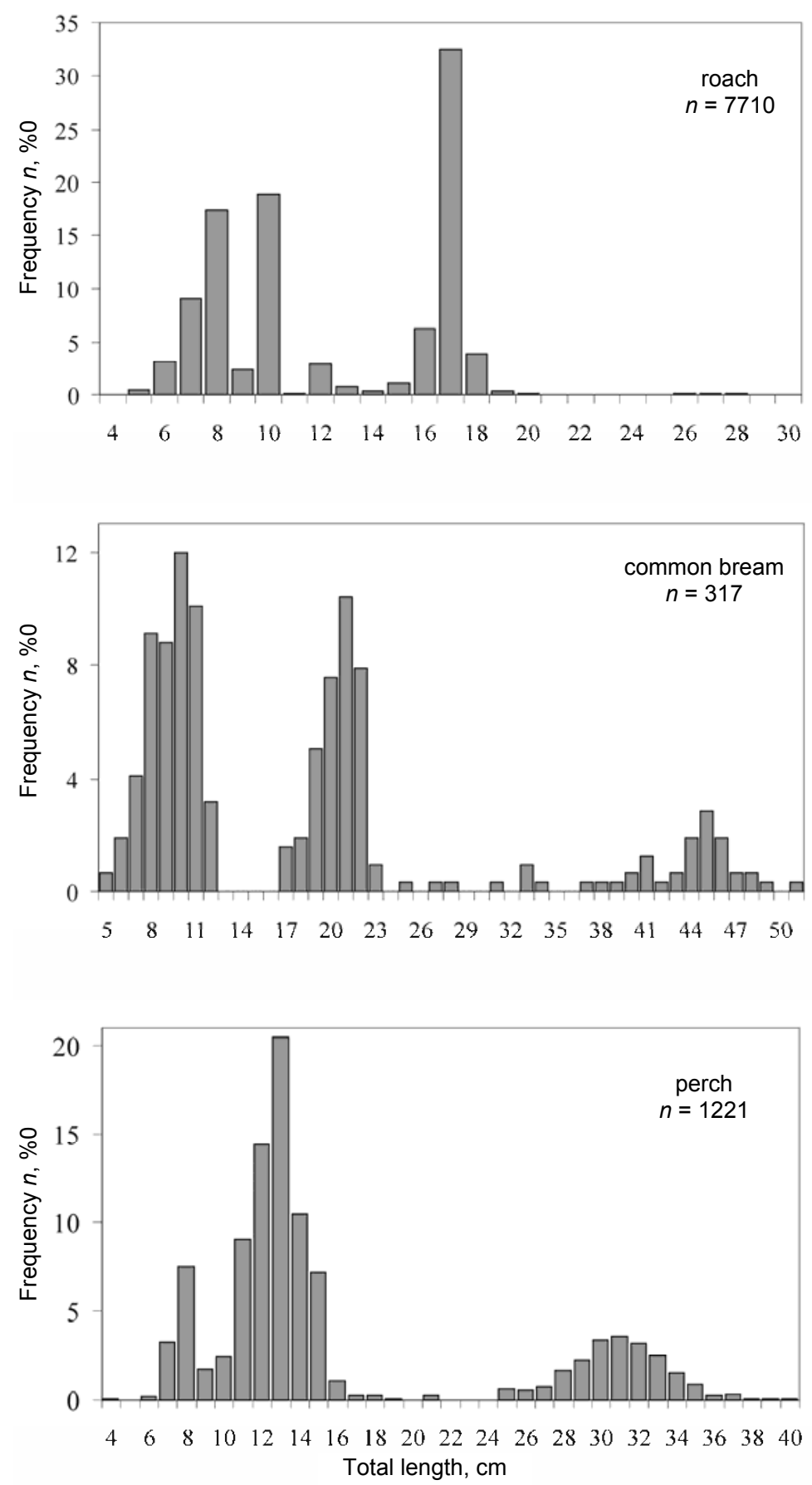

Fig. 1. Length frequency distribution of roach, common bream and perch in catches in the Malta Reservoir in 2008 
predatory fish, at the overall eutrophic character and production potential of the reservoir (GOŁDYN et al., 1997). The highest to that date biomass density estimate in the Malta Reservoir, amounting to $617.7 \mathrm{~kg} \cdot \mathrm{ha}^{-1}$, was recorded in 2000 (ANDRZEJEWSKI, unpublished). Stocking with predatory fish, mainly pike and pikeperch, in 2001-2002 and 2005-2008, had a varied effect on the biomass sizes observed during drainage in 2004 and 2008 (Fig. 2). In 2004 biomass density was $184.3 \mathrm{~kg} \cdot \mathrm{ha}^{-1}$, however primarily species of economic value were recorded and the proportion of predatory fish was nearly $67 \%$. In turn, in 2008, at the biomass density of $536.7 \mathrm{~kg} \cdot \mathrm{ha}^{-1}$ the share of predatory fish was only $20 \%$. This last value comes close to a sufficiently high proportion of piscivores in the total fish assemblage of 25:75\% predatory:non-predatory fish biomass ratio as suggested as an optimum structure for effective top-down control by MASTYŃSKI and WAJDOWICZ (1994), but still far away from 30:70\% ratio of STARMACH (1988) or 30-40:70$60 \%$ ratio of BENNDORF (1990).

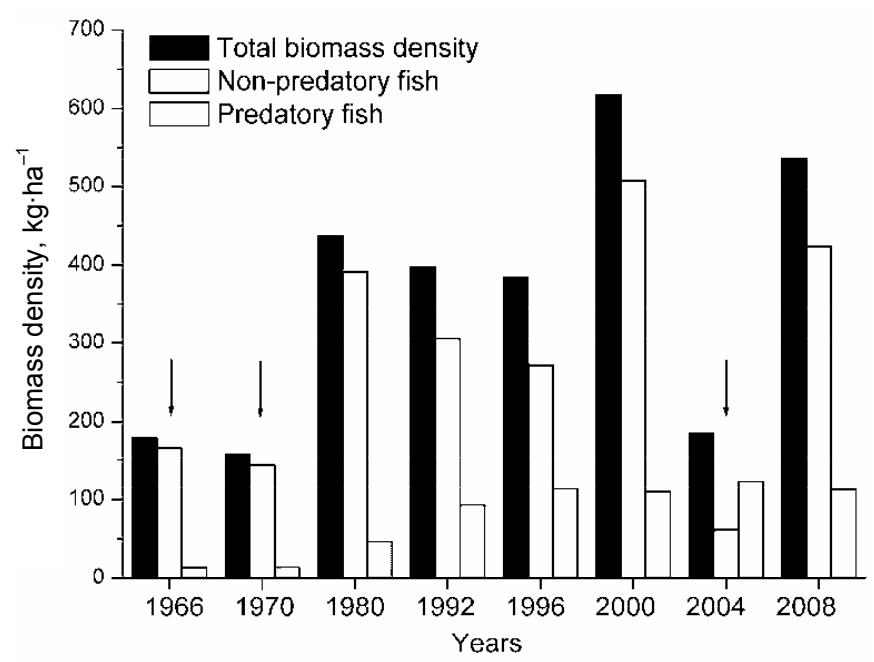

Fig. 2. Fish biomass in successive drainages of the Malta Reservoir between 1966 - 2008 (arrows indicate lower biomass density estimates due to the way of handling with catch; data from MASTYŃSKI and ANDRZEJEWSKI, 1996; ANDRZEJEWSKI, unpublished; this paper)

A high proportion of perch in the catch weight using multi-mesh gillnets, higher than in catches with the beach seine, which yield a more reliable picture of the fish fauna structure, only partly may result from the trend observed by PRCHALOVA et al. (2008) of overestimation of perch catches efficiency with the Nordic gillnets. A simpler explanation may be provided by the fact that roach, on a massive scale getting stuck and flapping in nets, attracted predators. Some of large perches, pikeperches and pikes caught itself when swallowing small roaches 
already stucked in Nordic gillnets. The low proportion of pike $(2.8 \%$ in the fish assemblage biomass), despite the earlier intensive stocking efforts, may be the effect of the limited amount of habitats suitable for this species as well as poaching. In the Malta Reservoir clusters of emerged vegetation, primarily common reed (Phragmites communis), narrow leaf cattail and common cattail (Typha angustifolia and T. latifolia), cover only $0.2 \%$ of the reservoir area, at the almost complete lack of submerged vegetation (GOŁDYN, 2000). According to GOŁDYN (2007) a serious drawback of stocking with summer and autumn fry of pike and pikeperch is its low survival rate, below 5\%, connected with the absence in the Malta Reservoir a natural refuge constituted by submerged vegetation. Also ŘíHA et al. (2009) stated that the absence of submerged vegetation has an adverse effect on the efficiency of stocking efforts and spawning success of pike.

In the biomass of cyprinids in the Malta Reservoir bream predominated up to the fourth drainage (in 1992). Its proportion in the fish biomass ranged from 37 to $82 \%$. Since 1996 bream share in fish assemblage biomass declined from $14.2 \%$ to $6.4 \%$ in 2008 . The growth of roach biomass share, from $28 \%$ in 1992 to $70.7 \%$ in 2008 was observed instead. Bream biomass density was $85.5 \mathrm{~kg} \cdot \mathrm{ha}^{-1}$ in 2000 , which amounted to $13.8 \%$ of fish biomass, while in the last drainage bream accounted for only $6.4 \%$ of all fish caught $\left(34.2 \mathrm{~kg} \cdot \mathrm{ha}^{-1}\right)$ (Fig. 3). Without additional biological data attempts to explain changes in the bream:roach biomass ratio could be just a mere speculation. Two basic factors could participate in this phenomenon. External one, the way the catch is carried on and handled subsequently. Internal one, connected with habitat and food availability for bream.

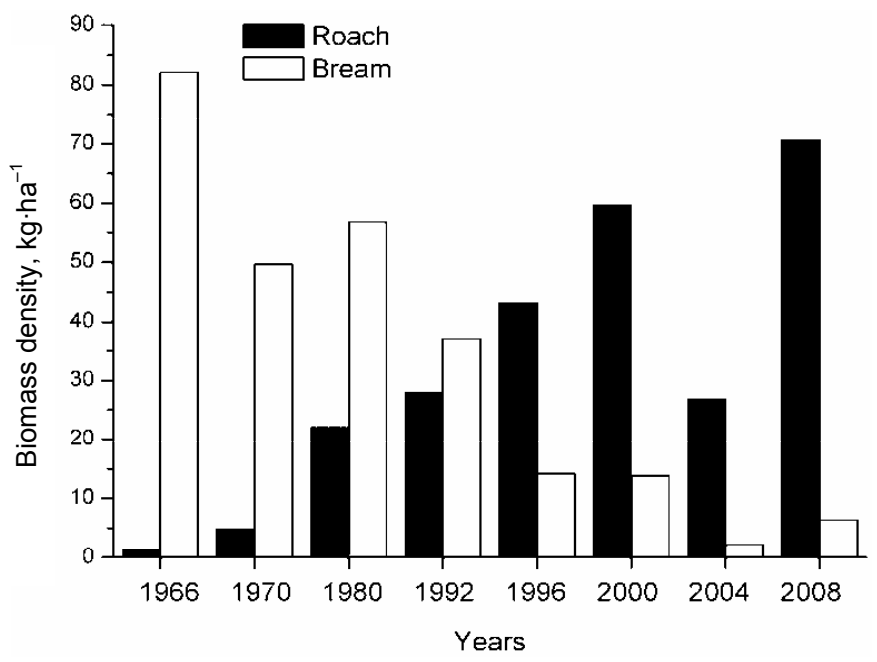

Fig. 3. Biomass of roach and bream in successive drainages of the Malta Reservoir between 1966-2008 (data from MASTYŃSKI and ANDRZEJEWSKI, 1996; ANDRZEJEWSKI, unpublished; this paper) 
Biomanipulation experiment conducted in the Malta Reservoir (GOŁDYN, 1996; GOŁDYN et al., 1997; 2003; GOŁDYN and MASTYŃSKI; 1998) showed that biomanipulation in a lowland, eutrophic reservoir does not always bring expected results, since it is very difficult to limit the extremely strong and effective, natural succession of plankton-feeding fish by promotion of predatory fish, i.e. pike and pikeperch.

However, there are examples from other reservoirs, that biomanipulation can be successful, at least with respect to fish and zooplankton. In a 533 ha, hypertrofic Bautzen Reservoir, Germany, the fish assemblage was dominated by zooplanktonovorous and benthivorous fish, with total biomass $200 \mathrm{~kg} \cdot \mathrm{ha}^{-1}$ at the end of '70s. In a long-term biomanipulation experiment stocking with predatory fish (pikeperch, pike, wels and eel) combined with catch restrictions led to the increase of the proportion of piscivores in the total fish biomass from 14 to over $50 \%$ and total biomass decrease to about $100 \mathrm{~kg} \cdot \mathrm{ha}^{-1}$ (BENNDORF, 1990; 1995). Thanks to stocking and predators enhancement the predator biomass have reached at least $25 \%$ of the total biomass in the deep, stratifying Wupper Reservoir, including a strong piscivorous perch population (SCHARF, 2008).

In the Malta Reservoir 8 to 13 fish species were recorded in commercial catches between 1966-1996. Grass carp (Ctenopharyngodon idella) and silver carp (Hypophthalmichthys molitrix) occurred in 1992 catches, as the result of stocking with these species. In 2000-2008 the number of species reported in commercial catches from the reservoir ranged from 10 to 11. In 2004 the Malta Reservoir was experimentally stocked with juveniles of the Atlantic sturgeon (Acipenser oxyrhynchus) in order to determine potential adaptation of this species in a reservoir. Apart Atlantic sturgeon two species caught in 2008, sunbleak (Leucaspius delineatus) with Nordic multi-mesh gillnets and gudgeon in electric catches, had never been caught with commercial gears in the Malta Reservoir before.

Fish biomass density recorded as the result of catches in $2008\left(536.7 \mathrm{~kg} \cdot \mathrm{ha}^{-1}\right)$ was very close to that estimated hydroacoustically $\left(550 \mathrm{~kg} \cdot \mathrm{ha}^{-1}\right)$ in the course of analyses using a split beam echo sounder with a horizontally directed beam, conducted simultaneously with fish catches (GODLEWSKA et al., 2009).

The fish biomass size in the reservoir is affected by its area, depth, thermal conditions, retention time, the character of the catchment and conducted fishery management, to mention just a few. Forming fish assemblages occupy a new environment, different from the natural habitat, undergo accelerated succession, combined with considerable fluctuations in biomass. RíHA et al. (2009) described changes in the fish biomass density in the Rímov Reservoir with an area of 210 ha, located in the sub-mountain region. In the first years of its operation biomass density for three species, i.e. roach, bream and perch, was as high as $600-700 \mathrm{~kg} \cdot \mathrm{ha}^{-1}$, of which perch accounted for $70 \%$. In the successive years biomass density decreased to $409 \mathrm{~kg} \cdot \mathrm{ha}^{-1}$, at the continued dominance of perch. After the collapse of 
perch population, biomass density stabilized at $130 \mathrm{~kg} \cdot \mathrm{ha}^{-1}$, while dominant species in the reservoir were bream and roach.

Biomass densities in the Gołuchów Reservoir of 35 ha, drained in 1979, 1987 and 1998, were as high as 507.6, 1066.2 and $1031.5 \mathrm{~kg} \cdot \mathrm{ha}^{-1}$ (ANDRZEJEWSKI and MASTYŃSKI, 2000; MASTYŃSKI, 1984; MASTYŃSKI and WAJDOWICZ, 1994). Estimated biomass densities did not take into consideration angling exploitation and small fish species such as bleak, gudgeon, weatherfish (Misgurnus fossilis), threespined stickleback and ruffe, which flowed out of the reservoir during its drainage. In turn, the last value of biomass density was obviously affected by the fact that reservoir stocking amounted to $608.1 \mathrm{~kg} \cdot \mathrm{ha}^{-1}$ in $1989-1997$. Biomass density in drained reservoirs Stańków (45.5 ha) and Krynice (39.7 ha), in which 90\% of catch weight consisted of Prussian carp (Carassius gibelio), was 524.3 and $403.9 \mathrm{~kg} \cdot \mathrm{ha}^{-1}$, respectively. In turn, in the larger Mosty Reservoir (395 ha) biomass density was only $112 \mathrm{~kg} \cdot \mathrm{ha}^{-1}$, but in the catch predominated roach $(24.2 \%)$, pike $(23.0 \%)$ and tench Tinca tinca $(20.8 \%)$, with the considerable share of perch (16.1\%) and bream (10.7\%) (MASTYŃSKI, 1985).

Estimates of biomass density in reservoirs of similar size, but conducted using different, indirect methods, yielded comparable results. PIVNIČKA and ŠVATORÁ (1988) estimated fish biomass in the Klíčava Reservoir (55 ha) by the tagging method. Mean biomass density of 12 species was $314 \mathrm{~kg} \cdot \mathrm{ha}^{-1}$, including $170 \mathrm{~kg} \cdot \mathrm{ha}^{-1}$ for roach and $30 \mathrm{~kg} \cdot \mathrm{ha}^{-1}$ for perch in 1964-1986. KUBEČKA and BOHM (1991) estimated fish biomass density in the Jordan Reservoir (with an area of 50 ha), using catches with a beach seine from a known area, at $607.5 \mathrm{~kg} \cdot \mathrm{ha}^{-1}$.

High biomass densities are not solely characteristic for small lowland reservoirs. Also in large reservoirs, such as the Zegrzyński, Siemianówka or Włocławek, which fishery utilized area ranges from 2500 to 6000 ha, biomass density reaches considerable levels, comparable with those of small reservoirs. In 1986, as the result of the Włocławek Reservoir poisoning, in a water body of 2200 ha a total of 456 ton dead fish were collected, i.e. $207 \mathrm{~kg} \cdot \mathrm{ha}^{-1}$ (WIŚNIEWOLSKI, 2000). Probably some fish managed to swim away to other parts of the reservoir or to the Vistula River, thus the above value is only a minimal estimate of biomass density. Analyzing the gillnets catch per unit effort in relation to fish biomass density in lakes, WIŚNIEWOLSKI (2002) estimated that biomass density in the Włocławek Reservoir is $450 \mathrm{~kg} \cdot \mathrm{ha}^{-1}$, in the Siemianówka Reservoir $600 \mathrm{~kg} \cdot \mathrm{ha}^{-1}$, and in the Zegrzyński Reservoir as much as $1380 \mathrm{~kg} \cdot \mathrm{ha}^{-1}$. SZLAKOWSKI and WIŚNIEWOLSKI (2001) estimated biomass density of the exploited white bream stock in the Zegrzyński Reservoir to range from 43 to $80 \mathrm{~kg} \cdot \mathrm{ha}^{-1}$, depending on the intensity of exploitation. In fish biomass of the Zegrzyński Reservoir bream, roach and probably also other species have an important share, thus biomass density may reach several hundred kilograms per ha ${ }^{-1}$.

In sub-mountain reservoirs, similarly as in lowland reservoirs, despite differences in depths, thermal conditions, water regime and habitat conditions the fish 
assemblage soon is dominated by bream and roach, significantly increasing its biomass.

In the course of the Tresna Reservoir drainage in 1976 (1030 ha, on the Sola River) 24 ton of fish were caught and biomass density based on results of tagging was estimated at $120 \mathrm{~kg} \cdot \mathrm{ha}^{-1}$, including bream at $82.7 \mathrm{~kg} \cdot \mathrm{ha}^{-1}$ and nase (Chondrostoma nasus) at $21.4 \mathrm{~kg} \cdot \mathrm{ha}^{-1}$ (EPLER and BIENIARZ, 1977). This result, for methodological reasons depending on the catch size, could have been higher, since only $1 / 3$ of originally planned yield was obtained (MASTYŃSKI and WAJDOWICZ, 1994). LYSAK and LIGASZEWSKI (1998), basing on the differences in gillnets catch per unit effort assessed the fish biomass density in the Tresna Reservoir at 180 $\mathrm{kg} \cdot \mathrm{ha}^{-1}$ before its complete drainage and at $90 \mathrm{~kg} \cdot \mathrm{ha}^{-1}$ after refilling in 1988-95.

JELONEK and AMIROWICZ (1987a), using Zippin removal method to successive catches obtained with a beach seine, estimated the mean fish biomass density in the sub-mountain Rożnów Reservoir (1500 ha utilized area) at $162.8 \mathrm{~kg} \cdot \mathrm{ha}^{-1}$. Bream, roach, pikeperch and perch constituted $71.3 \%$ of biomass. In turn, in the Goczałkowice Reservoir ( 2400 ha utilized area) they estimated the mean biomass density, using different fishing gears, at $181.4 \mathrm{~kg} \cdot \mathrm{ha}^{-1}$. The share of four species, i.e. bream, roach, pikeperch and perch, was $84.9 \%$ (JELONEK and AMIROWICZ, 1987b).

A drawback of the discussed estimates is the fact that in view of the low intensity of commercial exploitation or experimental catches, obtained catches per unit effort may not be the true indices of absolute biomass size, thus biomass density estimated on their basis is burdened with a very high error, underestimating rather than overestimating the actual values.

The mean commercial catch rate in the Goczałkowice Reservoir was 17.4 $\mathrm{kg} \cdot \mathrm{ha}^{-1}$ in 1986-2001 period (EPLER et al., 2005) and $18.0 \mathrm{~kg} \cdot \mathrm{ha}^{-1}$ in five reservoirs (Włocławek, Jeziorsko, Goczałkowice, Siemianówka and Zegrzyński) in 2006 (FALKOWSKI, 2007), which in comparison to the biomass densities cited above are very low values.

Also recreational fisheries can supply, though indirectly, additional data concerning fish biomass densities in reservoirs. BIENIARZ et al. (1990) on the base of direct control of anglers in the Rożnów Reservoir in 1981 and 1985-87, during the peak of fishing season lasting from 15 June to 15 September, estimated recreational catches to range from 17 to $96 \mathrm{~kg} \cdot \mathrm{ha}^{-1}$ and $49 \mathrm{~kg} \cdot \mathrm{ha}^{-1}$ in average. The results depended on the anglers frequency, which varied strongly, and individual angling results. WRONA and GUZIUR (2006) on the base of creel survey conducted on the 480 ha Poraj Reservoir in 1998-2000 estimated recreational catches to range from 132 to $232 \mathrm{~kg} \cdot \mathrm{ha}^{-1}$ and $192 \mathrm{~kg} \cdot \mathrm{ha}^{-1}$ in average per year. Despite these high yields they recommended restoration of gillnet fishery to reduce densities of stunted bream and roach populations. High fishery productivity of dam reservoirs was also shown by the results of investigations by WOŁOS et al. (2008). Those authors stated that in dam reservoirs of the Częstochowa and Katowice districts bream and 
carp (Cyprinus carpio) predominate in anglers catches and yields recorded in dam and other types of reservoirs ranged from 5 to $457 \mathrm{~kg} \cdot \mathrm{ha}^{-1}$. Recreational catch on Zegrzyński Reservoir in 1999-2001, estimated with the help of direct monitoring and individual catch registers, range from 10.2 to $13.0 \mathrm{~kg} \cdot \mathrm{ha}^{-1}$ (WIŚNIEWOLSKI et al., 2009), somehow lower, in comparison with average $30 \mathrm{~kg} \cdot \mathrm{ha}^{-1}$ per year during 1986-1989 (WIŚNIEWOLSKI et al., 2004) and the above yield estimates.

One has to keep in mind that recreational fisheries results are strongly influenced by a number of factors like reservoir biological productivity, fisheries management, reservoir availability for anglers and the last but not least, data reliability and proper methodology used to collect and process the data.

The high fish biomass density in reservoirs indicate not only on the potential biological productivity of reservoirs, bur also results in disadvantageous phenomena, such as a reduced growth rate of fish, development of parasitic diseases, and also contributes to eutrophication and deterioration of water quality. The objective of fishery management should be to modify fish assemblages, using net catches, angling, stocking and biomanipulation measures, to limit these undesirable effects.

\section{CONCLUSIONS}

1. A total of 16 fish species belonging to six families were recorded in research and beach seine catches in the Malta Reservoir in 2008.

2. Roach, Rutilus rutilus, is the most abundant species in fish assemblage, both in numbers and weight.

3. Fish biomass density in the Malta Reservoir during complete drainage in 2008 was $536.7 \mathrm{~kg} \cdot \mathrm{ha}^{-1}$, the second highest estimate in comparison with 617.7 $\mathrm{kg} \cdot \mathrm{ha}^{-1}$ in 2000.

4. The proportion of predatory fish in the fish assemblage biomass was $20.1 \%$.

5. Stocking with piscivorous species, meant as a biomanipulation measure, did not result with a higher proportion of predators in the total fish biomass.

Acknowledgements

This work was supported by the grant No. NN304 052234 from the Polish Ministry of Science and Higher Education.

\section{REFERENCES}

1. ANDRZEJEWSKI W., MASTYŃSKI J., 2000. Efekty całkowitego odwodnienia zbiornika zaporowego Gołuchów. W: Wybrane aspekty gospodarki rybackiej na zbiornikach zaporowych. (The results of drainage the dam reservoir Gołuchów. In: Selected aspects of fishery management in dammed reservoirs). Eds J. Szumiec, A. Pilarczyk, J. Mastyński. Proceedings from International Conference, Gołysz, 15-16 May 2000. Gołysz, Wydaw. ZIiGR PAN: 16-22. 
2. BENNDORF J., 1990. Conditions of effective biomanipulation; conclusions derived from whole-lake experiments in Europe. Hydrobiologia, 200/201: 187-203.

3. BENNDORF J., 1995. Possibilities and limits for controlling eutrophication by biomanipulation. Internationale Revue der Gesamten Hydrobiologie und Hydrographie, 80: 519-534.

4. Bieniarz P., Epler P., SyCH R., 1990. Połowy wędkarskie na rożnowskim zbiorniku zaporowym. (Fish catching by anglers in the Rożnow dam reservoir). Roczniki Naukowe PZW 3: 15-31.

5. CEN (European Committee for Standardization), 2005. EN 14757. Water quality - Sampling of fish with multi-mesh gill nets. Brussels: 1-27.

6. EPLER P., BIENIARZ K., 1977. Ichtiofauna zbiornika zaporowego Tresna. (Ichthyofauna of the Tresna Reservoir). Gospodarka Rybacka, 10: 8-10.

7. Epler P., Kuboszek A., LuszczeK-Trojnar E., Socha M., DrąG-KozaK E., 2005. The ichtiofauna of the Goczałkowice dam reservoir in southern Poland in the 1986-2001 period. Archives of Polish Fisheries, 13: 267-273.

8. FALKOWSKI S., 2007. Gospodarka rybacka w wybranych zbiornikach zaporowych w 2006 roku. W: Stan rybactwa w jeziorach, rzekach i zbiornikach zaporowych w 2006 roku. (Fishery management in selected dam reservoirs in 2006. In: Status of the fishery in lakes, rivers and dam reservoirs in 2006). Ed. M. Mickiewicz. Olsztyn, Wydaw. IRŚ: 85-89.

9. Godlewska M., DoroszczyK L., DŁugoszewski B., ANDRZejewski W., Wiśniewolski W., SzlaKOWSKI J., BURAS P., LigIĘZA J. 2009. Comparison of acoustic estimates of fish stock with fish census during reservoir draining. W: Underwater Acoustic Measurements: Technologies \& Results. Eds J.S. Papadakis, L. Bjørnø. $3^{\text {rd }}$ International Conference and Exhibition, Nafplion, Greece $21^{\text {st }}$ June$26^{\text {th }}$ June 2009 Proceedings, Foundation for Research \& Technology - Hellas, Institute of Applied Mathematics: $1013-1020$.

10. GoŁDYN R., 1996. Próby poprawy stanu czystości wody Zbiornika Maltańskiego metodą biomanipulacji. W: Zbiornik Malta w Poznaniu - Funkcja sportowo-rekreacyjna a rybactwo. (Attempts to improve water purity in the Malta reservoir by biomanipulation. In: The Malta Reservoir in Poznań - its sports and recreation function and fishery). Ed. J. Mastyński. Poznań, Malta 25.10.1996. Poznań: Wydaw. Polskie Tow. Rybackie: 13-32.

11. GoŁDYN R., 2000. Zmiany biologicznych i fizyczno-chemicznych cech jakości wody rzecznej pod wpływem jej piętrzenia we wstępnych, nizinnych zbiornikach zaporowych. (Changes in biological and physico-chemical characteristics of river water quality under the effect of its damming in lowland dam reservoirs). Ser. Biol. 65. Poznań, Wydaw. Nauk. UAM: 1-186.

12. GoŁDYN R., 2007. Biomanipulacja w zbiornikach wodnych jako metoda rekultywacji. (Biomanipulation in water reservoirs as a reclamation metod). Przegląd Komunalny, 190(6): 70-72.

13. Goldyn R., KozaK A., Romanowicz W., 1997. Food-web biomanipulation in the Maltański Reservoir. Hydrobiologia, 342/343: 327-333.

14. Goldyn R., JoniaK T., Kowalczewska-Madura K., KozaK A., 2003. Trophic state of a lowland reservoir during 10 years after restoration. Hydrobiologia, 506-509: 759-765.

15. GOŁDYN R., MASTYŃSKI J., 1998. Biomanipulation in the Maltański Reservoir. International Review of Hydrobiology, Special Issue 83: 393-400.

16. JeloneK M., Amirowicz A., 1987a. Density and biomass of fish in the Rożnów Reservoir (Southern Poland). Acta Hydrobiologica, 29: 243-251.

17. JeloneK M., Amirowicz A., 1987b. Composition, density and biomass of the ichthyofauna of the Goczałkowice Reservoir (Southern Poland). Acta Hydrobiologica, 29: 253-259.

18. KubeČKA J., BoHm M., 1991. The fish fauna of the Jordan reservoir, one of the oldest man-made lakes in central Europe. Journal of Fish Biology, 38: 935-950.

19. KubečKa J., Hohausová E., Matěna J., Peterka J., Amarasinghe U.S., Bonar S.A., Hateley J., Hickley P., SuURonen P., Tereschenko V., Welcomme R., Winfield I.J., 2009. The true picture of a lake or reservoir fish stock: A review of needs and progress. Fisheries Research, 96: 1-5. 
20. ŁYSAK A., LIGASZEWSKI M., 1998. Skład ichtiofauny zbiornika zaporowego Tresna przed i po całkowitym spuszczeniu (1988-1995). (Ichthyofauna of the dam reservoir Tresna before and after its total drainage (1988-1995)). Roczniki Naukowe PZW 11: 65-80.

21. MASTYŃSKi J., 1971. Jezioro Malta w Poznaniu jako zbiornik produkcyjny. (Lake Malta in Poznan as a productive reservoir). Gospodarka Rybacka, 12: 10-13.

22. MASTYŃSKI J., 1984. Fish biomass of drained small reservoirs. Polskie Archiwum Hydrobiologii, 31: 69-76.

23. MASTYŃSKI J., 1985. Gospodarka rybacka i możliwości produkcyjne wybranych zbiorników zaporowych Polski. (Fishery management and production capacity of selected dam reservoirs in Poland). Roczniki Naukowe AR w Poznaniu Rozprawy Naukowe, 146: 1-91.

24. MASTYŃSKI J., ANDRZEJEWSKI W., 1996. Biomasa ryb zbiornika Malta w trakcie kolejnych pięciu odwodnień. W: Zbiornik Malta w Poznaniu. Funkcja sportowo - rekreacyjna a rybactwo. (Fish biomass in the Malta Reservoir during five successive drainages. In: The Malta Reservoir in Poznan - its sports and recreation function and fishery). Ed. J. Mastyński. Poznań, Malta 25.10.1996. Poznań, Wydaw. Polskie Tow. Rybackie: 33-38.

25. MASTYŃSKI J., KILMASZYK P., 1994. Importance of fish fauna for the water quality of the Maltanski Reservoir. PTPN Prace Komisji Biologicznej, 74: 75-82.

26. MASTYŃSKI J., WAJDOWICZ Z., 1994. Rybactwo w zbiornikach zaporowych. (Fishery in dam reservoirs). Poznań, Wydaw. AR: 1-220.

27. PIVNIČKA K., ŠVATORÁ M., 1988. Living together of roach and perch with respect to their competition in the Klíčava Reservoir between 1964-1986. Acta Universitatis Carolinae Environmentalica, 2: $17-85$.

28. Prchalová M., KubeČKa J., Říha M., Litvín R., Čech M., Frouzová J., Hladík M., Hohausová E., Peterka J., VAŠEK M., 2008. Overestimation of percid fishes (Percidae) in gillnet sampling. Fisheries Research, 91: 79-87.

29. Ř́íha M., KubečKa J., VašEk M., Seda J., MrkvičKa T., Prchalová M., Matēna J., HladíK M., Čech M., Draštík V., Frouzová J., Hohausová E., Jarolím O., Jůza T., Kratochvíl M., PeTERKA J., TUŠER M., 2009. Long-term development of fish populations in the Rímov Reservoir. Fisheries Management and Ecology, 16: 121-129.

30. StARMACH J., 1988. Możliwości regulacji funkcjonowania ekosystemu Zbiornika Dobczyckiego. W: Biomanipulacja jako metoda biologiczna zachowania czystości wody w zbiornikach zaporowych. (Possibility of controling the ecosystem of the Dobczyce Reservoir. In: Biomanipulation as a biological method of water purity conservation in dam reservoirs). Mogilany, 16-17 May 1988. Publ. PZITS, 553: 139-143.

31. SCHARF W., 2008. Development of the fish stock and its manageability in the deep, stratifying Wupper Reservoir. Limnol, 38: 248-257.

32. Sych R., 1997. Kilka rozważań nad zagęszczeniem ryb, przykłady ze zbiorników zaporowych. W: Wędkarstwo w ochronie wód i rybostanów. (Some remarks on fish density, examples from dam reservoirs. In: Angling in protection of waters and fish stocks). Ed. T. Backiel. Scientific Conference, Łódź, 26-27 May 1997. Roczniki Naukowe PZW: 53-66.

33. SZLAKOWSKI J., WiŚNIEWOLSKI W., 2001. Biomasa ryb Zbiornika Zegrzyńskiego w aspekcie ich eksploatacji na przykładzie krapia Blicca bjoerkna (Linneaus, 1758). (Biomass of fish stocks from Zegrzyński Reservoir as a feature of their exploitation, with a reference to white bream stock, Blicca bjoerkna (Linneaus, 1758)). Supplementa ad Acta Hydrobiologica, 1: 67-76.

34. WAJDOWICZ Z., 1971. Opróżnianie z wody zbiorników zaporowych i jego znaczenie dla rybactwa. (Drainage of dam reservoirs and its importance for fishery management). Olsztyn, IRŚ, 49: 1-20.

35. WIŚNIEWOLSKI W., 2000. Eksploatowane zespoły ryb Zbiornika Włocławskiego przed i po katastrofie ekologicznej. W: Wybrane aspekty gospodarki rybackiej na zbiornikach zaporowych. (The exploited fish assemblage from Włocławek dam reservoir before and after an ecological disaster. In: Selected aspects of fishery management in dammed reservoirs). Eds J. Szumiec, A. Pilarczyk, 
J. Mastyński. Proceedings from International Conference, Gołysz, 15-16 May 2000. Gołysz, Wydaw. ZIiGR PAN: 152-165.

36. WIŚNIEWOLSKI W., 2002. Zmiany w składzie ichtiofauny, jej biomasa oraz odłowy w wybranych zbiornikach zaporowych Polski. (Changes in the ichtyofauna composition, biomass and catches in selected Polish dam reservoirs). Archives of Polish Fisheries, 10, Suppl. 2: 5-73.

37. WIŚNIEWOLSKI W., 2009. Uwarunkowania i prowadzenie gospodarki rybacko-wędakarskiej w zbiornikach zaporowych. (Conditions for the fisheries and angling management in dam reservoirs). Roczniki Naukowe PZW, 22: 141-161.

38. WiŚniewolski W., BorZęcKa I., Buras P., SZlakowski J., WoŁos A., 2004. Odłowy wędkarskie i sieciowe - wzajemne relacje na przykładzie zbiorników zaporowych Zegrzyńskiego i Siemianówki. (Angling and commercial catches - interrelations exemplified using the Zegrzyński and Siemianówka dam reservoirs). Archives of Polish Fisheries, 12, Suppl. 2: 345-357.

39. WiŚNIEWOLSKI W., WoŁos A., BORZĘCKA I., 2009. Assessing angling catches in dam reservoirs on the example of Zegrze Dam Reservoir. Archives of Polish Fisheries 17: 211-220.

40. WoŁos A., ChMielewski H., GrZegorCZyK J., MięTus A., 2008. Rejestracja połowów wędkarskich w wodach użytkowanych przez katowicki i częstochowski okręg Polskiego Związku Wędkarskiego w 2007 roku. (Records of angling catches in waters used by the Katowice and Częstochowa districts of the Polish Angling Association). Olsztyn, Wydaw. Edycja: 66-67.

41. Wrona J., GuZIUR J., 2006. Uwarunkowania wędkarskiego użytkowania zbiornika zaporowego Poraj. Część I. Połowy wędkarskie. (The conditions of angling on the Poraj Dam Reservoir. Part 1. Angling catches). Roczniki Naukowe PZW, 19: 123-140.

\section{STRESZCZENIE}

\section{Biomasa i struktura gatunkowa ichtiofauny Zbiornika Maltańskiego}

Słowa kluczowe: ichtiofauna, struktura gatunkowa, zagęszczenie biomasy, Zbiornik Maltański

Badania ichtiofauny w Zbiorniku Maltańskim przeprowadzono w 2008 r. w trzech etapach: (1) we wrześniu i w październiku z wykorzystaniem palenowych wontonów badawczych (Nordic gillnets); (2) w październiku i listopadzie w trakcie kolejnego odwodnienia zbiornika ryby były odławiane przez brygadę rybacką za pomoca przywłoki; (3) w listopadzie, po całkowitym odwodnieniu zbiornika, na dwóch stanowiskach w korycie Cybiny, biegnącym w czaszy zbiornika przeprowadzono elektropołowy. W trakcie badań każdorazowo oznaczano gatunki ryb, ich liczbę i masę.

W Zbiorniku Maltańskim w 2008 r. stwierdzono występowanie 16 gatunków ryb, należących do sześciu rodzin. W wontony nordyckie złowiono 4528 sztuk ryb, należących do 11 gatunków, o łącznej masie 149,5 kg. Udział płoci, gatunku dominującego w tych połowach, wyniósł $64,5 \%$ liczebności połowu i 38,8\% jego masy. Udział kolejnych dwóch gatunków, tj. okonia i jazgarza, wyniósł odpowiednio 16,8 i $11,5 \%$ liczebności oraz 25,8 i 4,5\% masy. W odłowach przywłoką łącznie pozyskano $34348,9 \mathrm{~kg}$ ryb, co w przeliczeniu na hektar powierzchni zbiornika, wyniosło $536,7 \mathrm{~kg} \cdot \mathrm{ha}^{-1}$ (powierzchnia $64 \mathrm{ha}$ ). Dominantem pod względem liczeb- 
ności (485 031 szt., 7578 szt. ha ${ }^{-1}$ ) i biomasy (24 283,4 kg, 70,7\%) była płoć. Udział drugiego pod względem liczebności i biomasy okonia wyniósł 8,9\% $(3062,5 \mathrm{~kg})$, a jego zagęszczenie wyniosło $1590 \mathrm{szt} \cdot \mathrm{ha}^{-1}$. Masa ryb z elektropołowów w korycie Cybiny wynosiła średnio $105 \mathrm{~kg}$. W połowach dominowała płoć, stanowiąc 93\% liczebności i 65,4\% jego masy. Udział okonia i sandacza wyniósł odpowiednio 3\% i 0,6\% liczebności oraz 4,7\% i 27,8\% masy.

Zagęszczenie biomasy ichtiofauny Zbiornika Maltańskiego podczas całkowitego odwodnienia w $2008 \mathrm{r}$. wyniosło $536,7 \mathrm{~kg} \cdot \mathrm{ha}^{-1}$, a po uwzględnieniu wyników elektropołowów - $577,7 \mathrm{~kg} \cdot \mathrm{ha}^{-1}$. Było ono znacznie większe, w stosunku do średniej ze wszystkich dotychczasowych odwodnień $\left(362,2 \mathrm{~kg} \cdot \mathrm{ha}^{-1}\right)$. Udział ryb drapieżnych w biomasie ichtiofauny wyniósł $20,1 \%$, natomiast gatunków niedrapieżnych $-79,9 \%$.

Reviewers:

Received 20.09.2010

Prof. Lech Kufel

Prof. Wiestaw Wiśniewolski 